\title{
The effect of a novel orally active selective PDE4 isoenzyme inhibitor (CDP840) on allergen-induced responses in asthmatic subjects
}

\author{
P.L. Harbinson*, D. MacLeod**, R. Hawksworth+, S. O'Toole**, P.J. Sullivan*, \\ P. Heath ${ }^{++}$, S. Kilfeather*, C.P. Page*, J. Costello*, S.T. Holgate**, T.H. Lee ${ }^{+}$
}

\begin{abstract}
The effect of a novel orally active selective PDE4 isoenzyme inhibitor (CDP840) on allergen-induced responses in asthmatic subjects. P.L. Harbinson, D. MacLeod, R. Hawksworth, S. O'Toole, P.J. Sullivan, P. Heath, S. Kilfeather, C.P. Page, J. Costello, S.T. Holgate, T.H. Lee. COERS Journals Ltd 1997.

ABSTRACT: Recent studies have suggested that theophylline, a nonspecific phospho-diesterase inhibitor, has useful anti-inflammatory actions in asthma. Phosphodiesterase 4 (PDE4) represents the predominant PDE isoenzyme present in inflammatory cells. PDE4 inhibitors might, therefore, have beneficial effects in asthma. Sideeffects, specifically nausea, have limited the use of existing agents. CDP840 is an orally active, potent and selective PDE4 inhibitor. We have examined the effect of CDP840 on the allergen-induced asthmatic response, its possible modes of action, and its tolerability at therapeutic doses.

A total of 54 patients were recruited to three double-blind, placebo-controlled studies. The first study examined the effect of CDP840 (15 mg b.i.d. for 9.5 days) on the allergen-induced asthmatic response in patients with known dual response to allergen. A second study examined the effect of CDP840 (15 mg b.i.d. for 9.5 days) on airway responsiveness to histamine. A third study examined whether single dose CDP840 (15 and $30 \mathrm{mg}$ ) had significant bronchodilatory effects.

In all studies, CDP840 was well-tolerated, with no patients reporting nausea. CDP840 did not lead to changes in baseline forced expiratory volume in one second (FEV1) as compared to placebo. The late asthmatic response (LAR) to allergen, expressed as area under the curve at 3-8 h (AUC3-8h), was inhibited by $30 \%$ $(p=0.016)$, an effect which persisted to the end of the observation period. The early asthmatic response (EAR) was unaffected, and there was no bronchodilatory effect at the doses used. Treatment with CDP840 did not affect bronchial hyperresponsiveness to histamine.

In conclusion, CDP840 significantly attenuated the late asthmatic response to allergen challenge in the absence of any bronchodilatory or histamine antagonist effect. This suggests that CDP840 may exert its effects via an anti-inflammatory mechanism.
\end{abstract}

Eur Respir J 1997; 10: 1008-1014.

\begin{abstract}
*Sackler Institute of Pulmonary Pharmacology, Dept of Respiratory Medicine, King's College Hospital Medical School, London, UK. **University Medicine, Southampton General Hospital, Southampton, UK. +Dept of Allergy and Respiratory Medicine, UMDS, Guy's Hospital, London, UK. ${ }^{++}$Celltech Therapeutics Ltd, 216 Bath Rd, Slough, Berks, UK.
\end{abstract}

Correspondence: P.L. Harbinson

Sackler Institute of Pulmonary Pharmacology, Dept of Respiratory Medicine King's College Hospital Medical School London

UK

Keywords: Asthma

CDP840

phosphodiesterase 4

Received: September 231996

Accepted after revision January 271997

Study funded by Celltech Therapeutics Ltd.
Asthma is characterized by reversible airways obstruction, inflammation and airways hyperresponsiveness. The recognition that, even in mild asthma, a significant amount of airway inflammation is present [1], has led to recommendation of the early use of anti-inflammatory agents in its treatment [2]. The mainstay of such treatment remains the use of corticosteroid agents, but concern about side-effects of this class of drug remains, particularly in children [3].

The nonspecific phosphodiesterase (PDE) inhibitor, theophylline, is a long-established treatment in asthma. In recent years, it has become increasingly clear that, in addition to its action as a bronchodilator, theophylline has important immunomodulatory and anti-inflammatory actions [4]. In man, theophylline inhibits the allergeninduced late asthmatic response (LAR) and associated hyperresponsiveness $[5,6]$. Six weeks of treatment with theophylline has been shown to reduce the number of activated eosinophils recruited to the airway following allergen challenge, and decrease the numbers of activated CD4+ cells in bronchoalveolar lavage (BAL) fluid postchallenge $[7,8]$. In another study, withdrawal of theophylline treatment in asthmatic patients was accompanied by a fall in activated CD4+ cells in the peripheral blood and a concomitant increase in T-cells within the bronchial epithelium [9].

Many of the actions of theophylline in asthma may well be due to its action as a nonspecific inhibitor of the PDE enzyme. The cyclic nucleotides, cyclic adenosine monophosphate (cAMP) and cyclic guanosine monophosphate (cGMP), play a key role in cellular regulation, and are inactivated within the cell by the action of PDE. Increases in cellular cAMP are associated with a generalized downregulation of inflammatory cell activity $[10,11]$. It has been postulated, therefore, that PDE inhibitors might have a role in the treatment of asthma 
$[12,13]$. At present, seven distinct PDE gene families are recognized (PDE 1-7), each with different tissue specificity [14]. PDE4 represents the predominant PDE isoenzyme present in the majority of inflammatory cells. Inhibition of the PDE4 isoenzyme suppresses activation of a wide range of inflammatory cells, including eosinophils [15-17], neutrophils [18], mononuclear cells [19, 20], macrophages [21] and basophils [22].

Selective PDE4 isoenzyme inhibitors have been demonstrated to inhibit the eosinophil infiltration induced by allergen in allergic animals [17, 23,24], including primates [25]. PDE4 inhibitors are effective in inhibiting microvascular leakage induced by a variety of proinflammatory mediators [26]. There is also evidence that, as well as enhancing nonadrenergic noncholinergic (NANC) relaxation [27], PDE4 inhibitors may have direct bronchodilatory effects $[28,29]$. No selective PDE4 inhibitor has yet been evaluated for its anti-inflammatory effects in man. The mixed PDE3/4 inhibitor, zardaverine, has been shown to elicit mild bronchodilatation in man, albeit at doses that elicit nausea and vomiting [30]. Rolipram, a PDE4 inhibitor, has been used in the treatment of depressive illness, but has been limited by side-effects, specifically nausea [31].

CDP840 is a novel, potent, selective inhibitor of PDE4 (median inhibitory concentration (IC50) $4 \mathrm{nM}$ against recombinant PDE4A), with over a 10,000 fold selectivity for PDE4 compared to other known classes of PDE [32]. In rats, CDP840 was effective in inhibiting interleukin-5 (IL-5)-induced pleural eosinophilia. When administered to sensitized guinea-pigs, CDP840 inhibited antigen-induced bronchospasm, and pulmonary eosinophil accumulation, and was effective in maintaining eosinophil peroxidase (EPO) levels [32]. In an allergic rabbit model, CDP840 was as effective as the corticosteroid agent, budesonide, in inhibiting antigen-induced pulmonary eosinophilia and airway hyperresponsiveness to histamine [33].

In the present study, we have investigated the effect of CDP840 on allergen-induced responses in subjects with mild allergic asthma. Furthermore, we have examined the ability of CDP840 to affect basal bronchial tone and to inhibit nonspecific bronchial hyperresponsiveness, as manifested by the response to histamine challenge.

\section{Methods}

A total of 54 asthmatic subjects with atopic asthma were recruited to the three parallel studies, at three independent centres. All were male nonsmokers maintained on inhaled short-acting beta-agonist alone. All subjects gave written informed consent. The studies received ethics approval from King's College Ethics Committee (Study 1), the Joint Southampton University Hospital Ethics Committee (Study 2), and Guy's Hospital Ethics Committee (Study 3). CDP840, (supplied by Celltech Therapeutics Ltd, UK), was administered throughout, at doses which had previously been shown to be welltolerated in healthy volunteers (data on file). The dosing period for the allergen response and bronchial hyperresponsiveness (BHR) studies was the maximum permitted under licensing regulations at the time of the study.

\section{Study population}

Allergen response study. Fourteen volunteers, aged 19-34 yrs (mean \pm SD age $26 \pm 4$ yrs), were recruited. At screening, all had baseline forced expiratory volume in one second (FEV1) $>70 \%$ of predicted (Cotes formula) (mean \pm SD $89 \pm 12 \%)$. All exhibited a positive skin response $(\geq 5$ $\mathrm{mm}$ wheal) to Dermatophagoides pteronyssinus (Der $p 1$ ), and a dual asthmatic response to inhaled Der $p 1$, defined as a $>20 \%$ fall in mean FEV1 within 30 min of antigen challenge (early asthmatic response (EAR)) and, subsequently, a $>20 \%$ fall in mean FEV1 in the period 3-8 h postchallenge (late asthmatic response (LAR)).

Bronchial hyperreactivity study. Twenty seven volunteers, aged $18-35$ yrs (mean \pm SD $24 \pm 6$ yrs), were recruited. All had baseline FEV $1>85 \%$ pred and a provocative concentration causing a $20 \%$ fall in FEV1 (PC20) to histamine of $<8 \mathrm{mg} \cdot \mathrm{mL}^{-1}$.

Bronchodilator study. Thirteen volunteers, aged 21-31 yrs (mean \pm SD $25 \pm 3$ yrs), were recruited. Baseline FEV1 ranged $47-86 \%$ (mean \pm SD $75 \pm 8 \%$ ). Reversibility to inhaled salbutamol, $200 \mu \mathrm{g}$, ranged $16-44 \%$.

\section{Procedures}

Allergen response study. Initial screening was performed to demonstrate the presence of a dual asthmatic response. Der $p 1$ (Alk, Horsholm, Denmark) was administered by tidal breathing via a Wright nebulizer, calibrated to deliver $0.13 \mathrm{~mL} \cdot \mathrm{min}^{-1}$, in increasing concentrations until such time as an EAR occurred or a concentration of 100,000 Standardized Quality (SQ) (Aquagen ${ }^{\circledR}$ SQ, Alk) $\cdot \mathrm{mL}^{-1}$ had been reached. In the presence of an EAR, monitoring was continued and a LAR was judged to have occurred if there was a secondary fall in mean FEV1 of $20 \%$ or more over the subsequent $8 \mathrm{~h}$.

Using a double-blind, placebo-controlled, cross-over design and following a 3 week wash-out period after the screening allergen challenge, patients were randomized to receive either $15 \mathrm{mg}$ b.i.d. CDP840 or placebo capsules for 9 days. The first dose was taken under supervision and was followed by blood pressure, pulse and FEV 1 readings over a period of $2 \mathrm{~h}$ to assess safety. The final dose, again supervised, was taken on the 10th day and was followed immediately by allergen challenge. After a 4 week wash-out period, subjects entered the second treatment phase. Allergen challenge on each of the two study days was performed by administration of the final concentration of Der $p 1$, which had produced a satisfactory dual response on the screening day. The mean of three FEV1 readings was recorded over $20 \mathrm{~min}$ at $5 \mathrm{~min}$ intervals, and then at $10 \mathrm{~min}$ intervals until $1 \mathrm{~h}$ after allergen exposure. FEV 1 readings continued, thereafter, at $30 \mathrm{~min}$ intervals for a further $7 \mathrm{~h}$.

Bronchial hyperreactivity study. Using a parallel group design, patients were allocated either $15 \mathrm{mg}$ b.i.d. CDP840 or placebo for a period of 9.5 days. The primary variable was bronchial responsiveness to histamine, defined as the provocative concentration of histamine (histamine 
acid phosphate in $0.9 \% \mathrm{NaCl}$,) producing a $20 \%$ fall in FEV1 (PC20) at $2 \mathrm{~h}$ after the final dose compared to baseline level. Histamine challenge was performed using the cumulative dose method, modified from the method described by CHAI [34]. Baseline FEV1 was calculated following inhalation of $0.9 \%$ saline via a System 22 Disposable Sidestream Nebulizer (Medic-Aid, Pagham, UK) for 2 min (mass median diameter $3 \mu \mathrm{m}$ at $6 \mathrm{~L} \cdot \mathrm{min}^{-1}$, respirable output $80 \%$ ). FEV1 was measured three times at $1 \mathrm{~min}$ and three times at $3 \mathrm{~min}$ postinhalation. The maximal FEV 1 values at $1 \mathrm{~min}$ and at 3 min were compared and the lower of the two measurements used as the baseline. Histamine was then delivered in doubling concentrations, the initial dose being $0.03 \mathrm{mg} \cdot \mathrm{mL}^{-1}$ rising to a maximum concentration of $8 \mathrm{mg} \cdot \mathrm{mL}^{-1}$. The challenge was terminated when a fall in FEV1 of at least $20 \%$ from the baseline value was achieved, or the maximum concentration of agonist $\left(8 \mathrm{mg} \cdot \mathrm{mL}^{-1}\right)$ was reached.

Patients who achieved a $20 \%$ fall in FEV1 following inhalation of $8 \mathrm{mg} \cdot \mathrm{mL}^{-1}$ histamine or less and who fulfilled the other entry criteria commenced dosing with CDP840 or placebo. The first dose was supervised and was followed by blood pressure, pulse and FEV1 readings over a period of $2 \mathrm{~h}$ to assess safety. After 9.5 days of dosing with drug or placebo, histamine challenge was repeated 2 and $6 \mathrm{~h}$ after the final treatment dose, patients being allowed a rescue dose of inhaled salbutamol 200 $\mu \mathrm{g}$ from a metered-dose inhaler (MDI) after each challenge.

Bronchodilator study. Baseline FEV1 and reversibility following dosing with $200 \mu \mathrm{g}$ of salbutamol from a MDI was assessed. Subjects who had a baseline FEV1 of $\leq 86 \%$ pred and showed $\geq 15 \%$ reversibility to salbutamol entered the study. Subjects received single oral doses of 15 and $30 \mathrm{mg}$ of CDP840 and placebo in a double-blind, three-arm, cross-over design, with a minimum of 2 weeks between each dose. FEV1 was measured over a period of $6 \mathrm{~h}$ after dosing.

Plasma CDP840 concentrations were measured at various time-points during all three studies. Both in the allergen and histamine challenge studies, the second to penultimate dose was unsupervised. Therefore, CDP840 was measured just prior to the final dose to confirm exposure to the drug. In the allergen challenge study, a further assessment of drug concentration was made 24 $\mathrm{h}$ after the final dose.

\section{Statistical analysis}

In the allergen challenge study, area under the curve (AUC) was calculated using the trapezium rule. A twotreatment, two-period, cross-over analysis of variance (ANOVA) was performed on the AUCs for the LAR (AUC3-8h), EAR (AUC0-3h) and on the AUC7-8h, allowing for the effects due to patient, period, carry-over and treatment. In each analysis, the presence of carry-over effect was investigated. The assumptions of normality and constant variance were checked to assess the validity of the analyses.

In the bronchial hyperresponsiveness study, absolute values of $\mathrm{PC} 20$ were log-transformed prior to analysis to improve the assumptions of normality of distribution required by the statistical methods. An analysis of covariance was performed on the PC20 values at 2 and $6 \mathrm{~h}$, using the screening value as a covariate. Assumptions of normality of distribution, homogeneity of variance and homogeneity of regression slopes were investigated in the analysis.

In the bronchodilator study, a three-period, cross-over ANOVA was performed on the change from baseline of maximal FEV1 measured between $15 \mathrm{~min}$ and $6 \mathrm{~h}$ postinhalation, allowing for the effects due to patient, period, carry-over and treatment. The presence of a treatment by period interaction and carry-over effect were investigated initially in each analysis. The assumptions of normality and constant variance were checked to assess the validity of the analyses. A p-value of less than 0.05 was considered significant.

\section{Results}

In each study, CDP840 was well-tolerated and no serious adverse events were reported. In particular none of the subjects in any of the three studies experienced nausea or vomiting. Of a total of 23 nonserious adverse events, six occurred during placebo periods and 17 during treatment with CDP840. Whilst the pattern of events seemed sporadic, there did appear to be a nonsignificant slight excess of headache in the CDP840-treated group. One patient in the allergen challenge study had mildly raised hepatic transaminases at his screening visit. These rose slightly during the placebo period but actually fell during the CDP840 treatment period. Subsequent assessment by a hepatologist revealed no significant abnormality in liver function, and because of the time scale of these transient abnormalities they were not felt to be drugrelated.

With the exception of one subject, who took part in the allergen challenge study, plasma drug concentrations confirmed exposure to study drug. This patient had no drug detected in blood taken prior to his final dose on the morning of his allergen challenge. However, $24 \mathrm{~h}$ after this final, supervised dose, CDP840 was present at a level comparable with the other subjects in the study, suggesting that its absence in the previous sample was not due to rapid clearance of drug in this patient. It was concluded, therefore, that he had been noncompliant and data from this patient were excluded from the analysis.

In the allergen challenge study, 9.5 days of treatment with CDP840 did not significantly affect baseline values of FEV1 (mean FEV1 3.52 and 3.46 L), on Day 1 and Day 10, respectively, and there was no significant difference between baseline FEV1 on either of the allergen challenge days (mean FEV1 3.53 and $3.46 \mathrm{~L}$, in placebo and active period, respectively). The percentage changes in FEV1 following allergen challenge are shown in figure 1. There was no statistically significant effect on the EAR, defined as the AUC0-3h, (13\% inhibition; $\mathrm{p}=$ $0.64)$. The LAR, defined as AUC3-8h, was significantly reduced $(30 \%$ inhibition; $\mathrm{p}=0.016)$ in the treatment arm as compared to placebo (table 1). The AUC7-8h remained significantly reduced in the treatment group (34\% inhibition; $\mathrm{p}=0.018$ ), i.e. the effect of drug treatment was persistent at the end of the observation period.

In the bronchial hyperresponsiveness study, 9.5 days of treatment with CDP840 had no effect on airways hyperresponsiveness to histamine either at 2 or $6 \mathrm{~h}$ after 


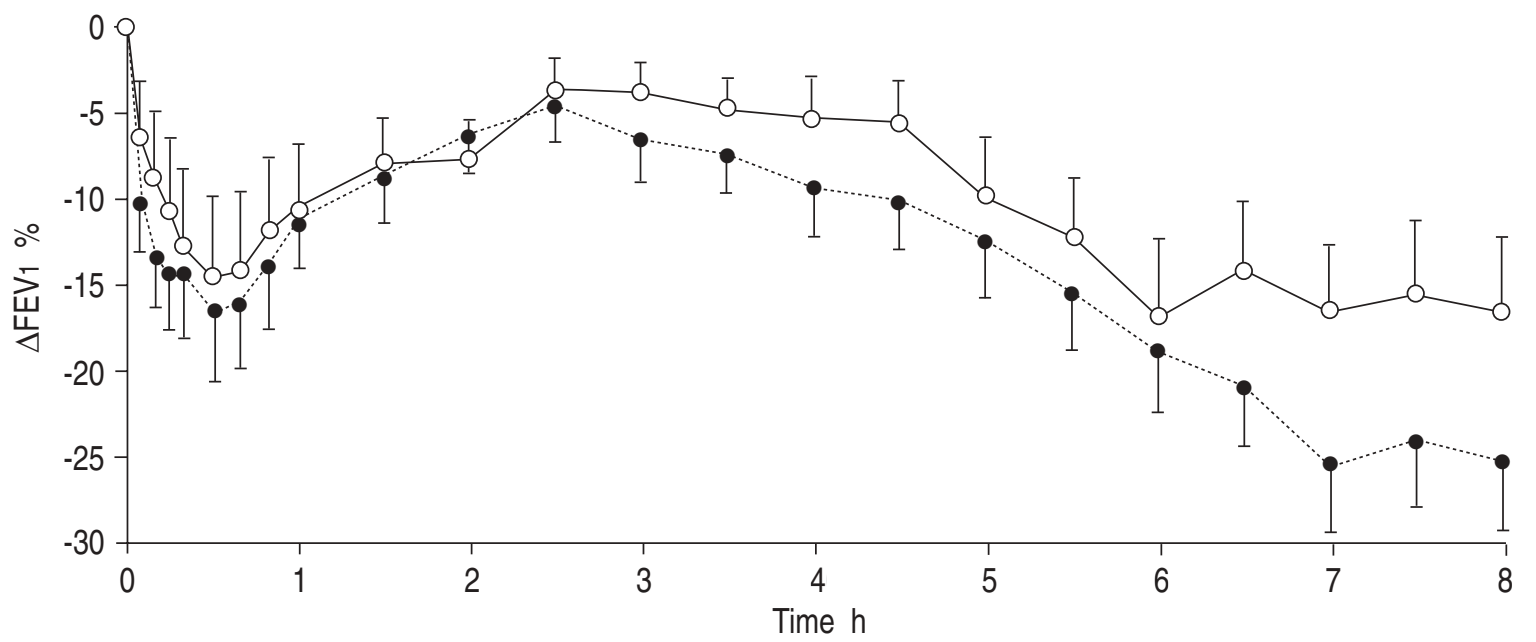

Fig. 1. - Effect of 9.5 days of treatment with CDP840 $15 \mathrm{mg}$ b.i.d. on the response to allergen, expressed as the percentage fall in FEV1 over the $8 \mathrm{~h}$ period following exposure $(\mathrm{n}=13)$. Values are expressed as mean \pm SEM. CDP840 : phosphodiesterase 4 inhibitor; $\Delta \mathrm{FEV}$ : change in forced expiratory volume in one second. ….......: placebo; ——- CDP840 $15 \mathrm{mg}$ b.i.d.

Table 1. - The effect of 9.5 days of treatment with CDP840 $15 \mathrm{mg}$ twice daily on the allergen-induced late asthmatic response expressed as maximal change in FEV1 and as area under the curve (AUC)

\begin{tabular}{|c|c|c|c|c|c|}
\hline & & & Placebo & $\begin{array}{c}\text { CDP840 } \\
15 \mathrm{mg} \text { b.i.d. }\end{array}$ & $\begin{array}{c}\text { Inhibition } \\
\%\end{array}$ \\
\hline Patients $n$ & $\mathrm{n}$ & & 13 & 13 & \\
\hline \multirow[t]{5}{*}{ FEV1 I } & Maximal change $\%$ & Adjusted mean* & -28.8 & -23.2 & 20 \\
\hline & & SEM & 1.94 & 1.94 & \\
\hline & Placebo - CDP840 & Mean difference & & -5.64 & \\
\hline & & $95 \%$ CI & & $(-11.67-0.39)$ & \\
\hline & & p-value & & 0.064 & \\
\hline \multirow[t]{5}{*}{$\mathrm{AUC}_{3}-8 \mathrm{~h}$} & $\% \cdot h$ & Adjusted mean* & 79.1 & 55.6 & 30 \\
\hline & & SEM & 5.82 & 5.82 & \\
\hline & Placebo - CDP840 & Mean difference & & 23.50 & \\
\hline & & $95 \% \mathrm{CI}$ & & $(5.37-41.63)$ & \\
\hline & & p-value & & 0.016 & \\
\hline \multirow[t]{5}{*}{$\mathrm{AUC7}-8 \mathrm{~h}$} & $\% \cdot h$ & Adjusted mean* & 24.6 & 16.3 & 34 \\
\hline & & SEM & 2.11 & 2.11 & \\
\hline & Placebo - CDP840 & Mean difference & & 8.25 & \\
\hline & & $95 \% \mathrm{CI}$ & & $(1.70-14.81)$ & \\
\hline & & p-value & & 0.018 & \\
\hline
\end{tabular}

*: adjusted for period and carry-over effects. FEV1: forced expiratory volume in one second; $95 \%$ CI: 95\% confidence interval; CDP840: phosphodiesterase 4 inhibitor.

Table 2. - Provocative concentration $\left(\mathrm{mg} \cdot \mathrm{mL}^{-1}\right)$ of histamine producing a $20 \%$ fall in $\mathrm{FEV} 1$ (PC20) at histamine challenge 2 and $6 \mathrm{~h}$ after oral dosing with CDP840 or placebo

\begin{tabular}{|c|c|c|c|}
\hline & Placebo & $\begin{array}{l}\mathrm{CDP} 84015 \mathrm{mg} \\
\text { b.i.d. }\end{array}$ & $\begin{array}{l}\text { Ratio of CDP840 } \\
\text { to placebo }\end{array}$ \\
\hline \multicolumn{4}{|l|}{$2 \mathrm{~h}$ after final dose } \\
\hline Geometric mean at screening & $\begin{array}{c}1.35(0.54-3.38) \\
(\mathrm{n}=11)\end{array}$ & $\begin{array}{c}0.75(0.30-1.88) \\
(\mathrm{n}=11)\end{array}$ & \\
\hline Geometric mean $2 \mathrm{~h}$ after final dose & $1.85(0.82-4.17)$ & $0.71(0.31-1.60)$ & \\
\hline $\begin{array}{l}\text { Geometric mean ratio to screening } \\
\text { p-value } \\
6 \mathbf{~ h ~ a f t e r ~ f i n a l ~ d o s e ~}\end{array}$ & $1.37(0.60-3.13)$ & $0.95(0.42-2.16)$ & $\begin{array}{c}0.51(0.20-1.32) \\
0.154\end{array}$ \\
\hline Geometric mean at screening & $\begin{array}{c}0.97(0.36-2.63) \\
(\mathrm{n}=12)\end{array}$ & $\begin{array}{c}0.75(0.26-2.15) \\
(\mathrm{n}=11)\end{array}$ & \\
\hline Geometric mean $6 \mathrm{~h}$ after final dose & $2.86(0.94-8.74)$ & $1.27(0.39-4.14)$ & \\
\hline $\begin{array}{l}\text { Geometric mean ratio to screening } \\
\text { p-value }\end{array}$ & $2.95(1.33-6.55)$ & $1.70(0.73-3.94)$ & $\begin{array}{c}0.55(0.18-1.63) \\
0.262\end{array}$ \\
\hline
\end{tabular}

Values in parentheses are 95\% confidence intervals. FEV1: forced expiratory volume in one second; CDP840: phosphodiesterase 4 inhibitor. 
Table 3. - Maximal percentage change in forced expiratory volume in one second from baseline $\left(\triangle F E V_{1}\right)$ following single doses of CDP840

\begin{tabular}{|c|c|c|}
\hline & $\triangle \mathrm{FEV}_{1} \%$ & p-value \\
\hline Placebo & $12.8 \quad(6.0-19.6)$ & \\
\hline CDP840 $15 \mathrm{mg}$ & $6.0 \quad(-0.9-12.9)$ & \\
\hline CDP840 $30 \mathrm{mg}$ & $11.8 \quad(4.2-19.4)$ & \\
\hline $\begin{array}{l}\text { Difference between placebo } \\
\text { and CDP840 } 15 \mathrm{mg}\end{array}$ & $-6.7(-16.4-3.0)$ & 0.16 \\
\hline $\begin{array}{l}\text { Difference between placebo } \\
\text { and CDP840 } 30 \mathrm{mg}\end{array}$ & $-1.0(-10.8-8.8)$ & 0.83 \\
\hline
\end{tabular}

Values are presented as means, and $95 \%$ confidence intervals in parentheses. CDP840: phosphodiesterase 4 inhibitor.

the final dose, nor was there any difference between the active and placebo treatment groups at either time-point (table 2). Whilst the geometric mean $\mathrm{PC} 20$ in the placebo group was almost double that for the CDP840 group, it is unlikely that this influenced the outcome of the study, since the treatment groups were compared after adjusting for the screening values.

There was no significant difference in change in FEV1 following dosing with 15 or $30 \mathrm{mg}$ CDP840 compared with placebo (table 3 ). In addition, no bronchodilatory effect was observed following the first dose of CDP840 either in the allergen challenge or bronchial hyperresponsiveness study.

\section{Discussion}

Our results show that the novel, orally active, selective PDE4 isoenzyme inhibitor, CDP840 has a statistically significant effect on the allergen-induced LAR. This effect was achieved using a dose regimen that did not elicit nausea or any other noteworthy side-effects, a problem that has hampered earlier clinical development of PDE4 inhibitors. The significant inhibitory effect of CDP840 against the allergen-induced LAR was not accompanied by any significant inhibition of the acute bronchoconstrictor response to allergen.

The dual asthmatic response is seen in a significant proportion of atopic asthmatics following exposure to allergen. The EAR begins almost immediately following exposure to allergen, reaches its peak at 15-20 min and is followed by resolution over the next $1-2 \mathrm{~h}$. This process, involving the actions of histamine, prostaglandin $\mathrm{D}_{2}$ and cysteinyl leukotrienes $\left(\mathrm{LTC}_{4}, \mathrm{LTD}_{4}, \mathrm{LTE}_{4}\right)$ is felt to be largely mast cell-dependent [35]. The LAR occurs 3-8 $\mathrm{h}$ after exposure to allergen and is associated with a marked influx of inflammatory cells (mast cells, eosinophils, neutrophils and lymphocytes) into the submucosa and epithelium [36]. At this time, there is a significant increase in the numbers of eosinophils in BAL fluid [37], a finding that persists for up to $96 \mathrm{~h}$ following exposure to allergen [38]. As the LAR is accompanied by inflammatory cell recruitment and often by an associated increase in BHR, it is considered to be a useful model of airway inflammation [39]. Corticosteroids, sodium cromoglycate, nedocromil sodium, theophylline and leukotriene antagonists are all successful in attenuating the LAR and the accompanying BHR [6, 39-41]. Treatment with theophylline, as well as attenuating the
LAR, is associated with a decrease in activated eosinophils in bronchial biopsies $24 \mathrm{~h}$ after allergen exposure [8]. Corticosteroids and low-dose theophylline have little effect on the EAR.

CDP840 had no effect on the allergen-induced EAR. It is, therefore, unlikely that, at the doses used, CDP840 is influencing the mast cell mediator release responsible for the EAR; an observation consistent with previous studies in this clinical model with the nonselective PDE inhibitor theophylline. At doses clearly influencing the LAR induced by allergen, CDP840 failed to modify basal lung function. CDP840, at both doses, did not significantly affect basal airway calibre in patients with demonstrable $\beta_{2}$-agonist sensitive bronchoconstriction. Moreover, CDP840 did not significantly modify histamine-induced bronchoconstriction, confirming that at these doses CDP840 is not acting as a bronchodilator. The inability of CDP840 to influence histamineinduced bronchoconstriction also suggests that the ability of this drug to influence the LAR is not via functional antagonism of released constrictor mediators.

It seems likely, therefore, that the inhibition of the LAR by CDP840 is via an anti-inflammatory action, since it is well-recognized that other agents which modify the LAR, such as glucocorticosteroids and theophylline, inhibit inflammatory cell infiltration into the airway mucosa [8, 42-44]. This is consistent with evidence from experimental models of airways inflammation, in which it is well-documented that CDP840, like other classes of selective PDE4 inhibitor, can have marked antiinflammatory actions, often at doses not causing bronchodilatation [23, 32, 33].

In this study, we observed no effect of CDP840 on BHR. A similar marginal effect on BHR but substantial effect on the allergen response has been described following short-term treatment with steroids [45]. Whilst established anti-inflammatory agents, such as steroids, reduce BHR, most studies have examined this effect after two or more weeks of treatment. Moreover, the maximal effects of treatment may not be seen for several weeks or more [46]. It is possible, therefore, that the treatment period used in this study was insufficient to clearly establish whether or not CDP840 has an effect on BHR. In addition, some studies have suggested that route of administration may be important. In a study comparing 3 weeks of treatment with oral prednisolone, $12.5 \mathrm{mg}$ daily, to inhaled beclomethasone, 1,200 $\mu \mathrm{g}$ daily, both had similar beneficial effects on recorded peak expiratory flow rate. Prednisolone, as opposed to beclomethasone, however, failed to affect BHR [47]. It is clear, therefore, that further studies would be necessary to adequately assess the effects of CDP840 on BHR and relate this to our observed effect on the LAR to allergen.

In conclusion, therefore, CDP840 is an orally active agent, which proved effective in attenuating the late asthmatic response to allergen, and was well-tolerated. Our results are consistent with this effect being mediated via an anti-inflammatory mechanism. This is the first demonstration that this class of drug may be effective in a clinical model of asthma. In the future, it is anticipated that selective phosphodiesterase 4 (PDE4) inhibitors may emerge as a new anti-inflammatory therapy in the treatment of allergic diseases, such as asthma. 
Acknowledgements: The authors would like to thank C. Novak for her invaluable assistance in the statistical analysis, and A. Farnsworth and N. Cox for their assistance with the study.

\section{References}

1. Beasley R, Roche WR, Roberts JA, Holgate ST. Cellular events in the bronchi in mild asthma and after bronchia provocation. Am Rev Respir Dis 1989; 139: 806-817.

2. British Thoracic Society. Guidelines on the management of asthma: statement by the British Thoracic Society. Thorax 1993; 48 (Suppl. 2): S1-S24.

3. Tinkelman DG, Reed CE, Nelson HS, Offord KP. Aerosol beclomethasone dipropionate compared with theophylline as primary treatment of chronic, mild-to-moderately severe asthma in children. Pediatrics 1993; 92: 64-77.

4. MacLeod D, Djukanovic R. Low-dose theophylline: a new anti-inflammatory role in asthma management? Monaldi Arch Chest Dis 1996; 51: 30-34.

5. Crescioli S, Spinazzi A, Plebani M, et al. Theophylline inhibits early and late asthmatic reactions induced by allergens in asthmatic subjects. Ann Allergy 1991; 66: 245-251.

6. Ward AJ, McKenniff M, Evans JM, Page CP, Costello JF. Theophylline, an immunomodulatory role in asthma? Am Rev Respir Dis 1993; 147; 518-523.

7. Jaffar Z, Sullivan PJ, Page CP, Costello J. Low-dose theophylline modulates T-lymphocyte activation in allergen-challenged asthmatics. Eur Respir J 1996; 9: 456-462.

8. Sullivan PJ, Bekir S, Jaffar Z, Page CP, Jeffrey P Costello J. Anti-inflammatory effects of low-dose oral theophylline in atopic asthma. Lancet 1994; 343: 1006-1008.

9. Kidney J, Dominguez M, Taylor PM, Rose M, Chung $\mathrm{KF}$, Barnes PJ. Immunomodulation by theophylline in asthma: demonstration by withdrawal of therapy. Am J Respir Crit Care Med 1995; 151: 1907-1914.

10. Bourne HR, Lichtenstein LM, Melmon KL, Henney CS, Weinstein Y, Shearer GM. Modulation of inflammation and immunity by cyclic AMP. Science 1974; 184(132): $19-28$.

11. Plaut M, Marone G, Gillespie E. The role of cyclic AMP in modulating cytotoxic T-lymphocytes. II. Sequential changes during culture in responsiveness of cytotoxic lymphocytes to cyclic AMP-active agents. J Immunol 1983; 131: 2945-2952.

12. Giembycz MA, Dent G. Prospects for selective cyclic nucleotide phosphodiesterase inhibitors in the treatment of bronchial asthma. Clin Exp Allergy 1992; 22: 337-344.

13. Torphy TJ, Undem BJ. Phosphodiesterase inhibitors: new opportunities for the treatment of asthma. Thorax 1991; 46: 512-523.

14. Beavo JA. Cyclic nucleotide phosphodiesterases: functional implications of multiple isoforms. Physiol Rev 1995; 75: 725-748.

15. Dent G, Giembycz MA, Evans PM, Rabe KF, Barnes PJ. Suppression of human eosinophil respiratory burst and cyclic AMP hydrolysis by inhibitors of type IV phosphodiesterase: interaction with the beta-adrenoceptor agonist, albuterol. J Pharmacol Exp Ther 1994; 271: 1167-1174.

16. Hatzelmann A, Tenor H, Schudt C. Differential effects of nonselective and selective phosphodiesterase inhibitors on human eosinophil functions. Br J Pharmacol 1995; 114: 821-831.
17. Karlsson JA, Souness J, Webber S, Pollock K, Raeburn D. Anti-inflammatory effects of the novel phosphodiesterase IV inhibitor, RP 73401. Int Arch Allergy Immunol 1995; 107: 425-426.

18. Nielson CP, Vestal RE, Sturm RJ, Heaslip R. Effects of selective phosphodiesterase inhibitors on the polymorphonuclear leukocyte respiratory burst. J Allergy Clin Immunol 1990; 86: 801-808.

19. Cooper KD, Kang K, Chan SC, Hanifin JM. Phosphodiesterase inhibition by Ro20-1724 reduces hyper-IgE synthesis by atopic dermatitis cells in vitro. $J$ Invest Dermatol 1985; 84: 477-482.

20. Essayan DM, Huang SK, Undem BJ, Kagey Sobotka A, Lichtenstein LM. Modulation of antigen- and mitogeninduced proliferative responses of peripheral blood mononuclear cells by nonselective and isozyme selective cyclic nucleotide phosphodiesterase inhibitors. J Immunol 1994; 153: $3408-3416$

21. Schade FU, Schudt C. The specific type III and IV phosphodiesterase inhibitor, zardaverine, suppresses formation of tumor necrosis factor by macrophages. Eur $J$ Pharmacol 1993; 230: 9-14.

22. Peachell PT, Undem BJ, Schleimer RP, et al. Preliminary identification and role of phosphodiesterase isozymes in human basophils. J Immunol 1992; 148: 2503-2510.

23. Banner KH, Page CP. Acute versus chronic administration of phosphodiesterase inhibitors on allergen-induced pulmonary cell influx in sensitized guinea-pigs. $\mathrm{Br} J$ Pharmacol 1995; 114: 93-98.

24. Underwood DC, Kotzer CJ, Bochnowicz S, et al. Comparison of phosphodiesterase III, IV and dual III/IV inhibitors on bronchospasm and pulmonary eosinophil influx in guinea-pigs. J Pharmacol Exp Ther 1994; 270: 250-259.

25. Turner CR, Andresen CJ, Smith WB, Watson JW. Effects of rolipram on responses to acute and chronic antigen exposure in monkeys. Am J Respir Crit Care Med 1994; 149: 1153-1159.

26. Ortiz JL, Cortijo J, Valles JM, Bou J, Morcillo EJ. Rolipram inhibits airway microvascular leakage induced by platelet-activating factor, histamine and bradykinin in guinea-pigs. J Pharm Pharmacol 1993; 45: 1090-1092.

27. Fernandes LB, Ellis JL, Undem BJ. Potentiation of nonadrenergic noncholinergic relaxation of human isolated bronchus by selective inhibitors of phosphodiesterase isozymes. Am J Respir Crit Care Med 1994; 150: 13841390.

28. Cortijo J, Bou J, Beleta J, et al. Investigation into the role of phosphodiesterase IV in bronchorelaxation, including studies with human bronchus. Br J Pharmacol 1993; 108: 562-568.

29. Raeburn D, Underwood SL, Lewis SA, et al. Antiinflammatory and bronchodilator properties of RP 73401, a novel and selective phosphodiesterase type IV inhibitor. Br J Pharmacol 1994; 113: 1423-1431.

30. Brunnee T, Engelstatter R, Steinijans VW, Kunkel G. Bronchodilatory effect of inhaled zardaverine, a phosphodiesterase III and IV inhibitor, in patients with asthma. Eur Respir J 1992; 5: 982-985.

31. Scott AI, Perini AF, Shering PA, Whalley LJ. In-patient major depression: is rolipram as effective as amitriptyline? Eur J Clin Pharmacol 1991; 40: 127-129.

32. Hughes B, Howat D, Lisle $\mathrm{H}$, et al. The inhibition of antigen-induced eosinophilia and bronchoconstriction by CDP840, a novel stereo-selective inhibitor of phosphodiesterase type 4. Br J Pharmacol 1996; 118: 11831191. 
33. Gozzard N, El-Hashim A, Herd CM, et al. Effect of the glucocorticosteroid budesonide and a novel phosphodiesterase type 4 inhibitor, CDP840, on antigen-induced airway responses in neonatally-immunised rabbits. $\mathrm{Br} \mathrm{J}$ Pharmacol 1996; 118: 1201-1208.

34. Chai H. Standardisation of bronchial inhalation challenge procedures. J Allergy Clin Immunol 1975; 56: 323-327.

35. Holgate ST. The mast cell and its function in allergic disease. Clin Exp Allergy 1991; 21 (Suppl. 3): 11-16.

36. Montefort S, Gratziou C, Goulding D, et al. Bronchial biopsy evidence for leukocyte infiltration and upregulation of leukocyte-endothelial cell adhesion molecules 6 hours after local allergen challenge of sensitized asthmatic airways. J Clin Invest 1994; 93: 1411-1421.

37. Gratziou C, Carroll M, Montefort S, Teran LM, Howarth $\mathrm{PH}$, Holgate ST. Inflammatory and T-cell profile of asthmatic airways 6 hours after local allergen provocation. Am J Respir Crit Care Med 1996; 153: 515-520.

38. Metzger WJ, Zavala D, Richerson HB, et al. Local allergen challenge and bronchoalveolar lavage of allergic asthmatic lungs: description of the model and local airway inflammation. Am Rev Respir Dis 1987; 135: 433440.

39. Cockcroft DW, Murdock KY. Comparative effects of inhaled salbutamol, sodium cromoglycate, and beclomethasone dipropionate on allergen-induced early asthmatic responses, late asthmatic responses, and increased bronchial responsiveness to histamine. J Allergy Clin Immunol 1987; 79: 734-740.
40. Holgate ST, Bradding P, Sampson AP. Leukotriene antagonists and synthesis inhibitors: new directions in asthma therapy. J Allergy Clin Immunol 1996; 98: 1-13.

41. Pelikan Z, Pelikan Filipek M, Remeijer L. Effects of disodium cromoglycate and beclomethasone dipropionate on the asthmatic response to allergen challenge. II. Late asthmatic response (LAR). Ann Allergy 1988; 60: 217-225.

42. Djukanovic R, Wilson JW, Britten KM, et al. Effect of an inhaled corticosteroid on airway inflammation and symptoms in asthma. Am Rev Respir Dis 1992; 145: 669-674.

43. Jeffery PK, Godfrey RW, Adelroth E, Nelson F, Rogers A, Johansson SA. Effects of treatment on airway inflammation and thickening of basement membrane reticular collagen in asthma: a quantitative light and electron microscopic study. Am Rev Respir Dis 1992; 145: 890-899.

44. Lundgren R, Soderberg M, Horstedt P, Stenling R. Morphological studies of bronchial mucosal biopsies from asthmatics before and after ten years of treatment with inhaled steroids. Eur Respir J 1988; 1: 883-889.

45. Paggiaro PL, Dente FL, Vagaggini B, et al. Salbutamol plus beclomethasone dipropionate, but not salbutamol alone, completely prevent early and late asthmatic responses to allergen. Respir Med 1991; 85: 401-406.

46. Kraan J, Koeter GH, Van Der Mark TW, et al. Dosage and time effects of inhaled budesonide on bronchial hyperreactivity. Am Rev Respir Dis 1988; 137: 44-48.

47. Jenkins CR, Woolcock AJ. Effect of prednisone and beclomethasone dipropionate on airway responsiveness in asthma: a comparative study. Thorax 1988; 43: 378-384. 